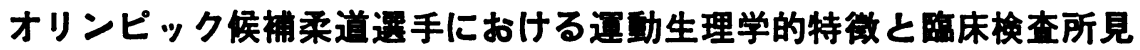

\author{
長 谷 弘 記* 中村良 一* 海老根 東 雄** \\ 赤池 真***露木和 夫*** 米田一平****

\section{EXERCISE PHYSICAL CHARACTERISTICS AND LABORATORY FINDINGS IN JAPANESE ELITE JUDO ATHLETES}

\author{
Hiroki Hase, Ryoichi Nakamura, Kunio Ebine, \\ Makoto Akaike, Kazuo Tsuyuki and IPei Yoneda
}

\begin{abstract}
A study was performed to evaluate the physical exercise characteristics of 29 Japanese elite judo athletes by treadmill exercise test. Functional aerobic impairment (FAI), heart rate impairment (HRI) and peripheral circulatory impairment (PCI) in the judo athletes were not significantly different from those of normal sedentary subjects. However, myocardial aerobic impairment (MAI) was lower than in normal sedentary subjects. $\% \dot{\mathrm{V}}{ }_{2}$ max at the anaerobic threshold (AT) was $57.5 \pm 3.3 \%$ in male, and $57.0 \pm 4.3 \%$ in female judo athletes. $\% \mathrm{HRmax}$ at AT was $72.4 \pm 3.8 \%$ in males, and $75.2 \pm 5.3 \%$ in females.

These findings suggest that functional aerobic capacity and peripheral circulatory function in Japanese elite judo athletes are not significantly different from those of normal sedentary subjects, but that judo athletes have high left ventricular function.

The blood biochemical profile and urinalysis date revealed that values of muscle injury enzymes, plasma uric acid and cholesterol were increased with relatively high freqency in elite judo athletes. Similar data were also obtained in individuals with suspected diabetic nephropathy and rhabdomyolysis.
\end{abstract}

(Jpn. J. Phys. Fitness Sports Med. 1990, $39: 341 \sim 349$ )

key words : Japanese elite judo athletes, Functional aerobic impairment, Anaerobic thresh. old

\section{I. 粕}

言

オリンピック競技種目に採用されて以来, 柔道 の国際的発展にはめざましいものがある.しかし ながら，他の競技種目に比して，柔道選手の競技 能力增強を目的とした研究は極めて少ない. 近年, これらの反省から日本柔道連盟内に医科学委員会
が設置され、コーチやトレーナーのみならずスポ ーツドクター等も含め, それぞれの専門的立場か ら競技能力増強に関しての検討がなされ始めた. そこで，今回著者らは日本柔道選手の競技力増 強を考える上での基本的研究として，日本を代表 する一流柔道選手の運動生理学的特徴を評価する とともに，医学的立場より強化合宿中に打る選

\footnotetext{
$*$ 東邦大学第三内科

東京都目黑区大橋2-17-6

3 rd Department of Internal Medicine, TOHO University School of Medicine

**東邦大学大橋病院心灆血管外科

東京都目黒区大橋2-17-6

Department of Cardiovascular surgery, OHASI Hospital, TOHO

University

***小田原循環器病院 小田原市矢作296-1

Odawara Cardiovascular Hospital

****全日本柔道連盟医科学委員会

Medical Science Committee, All Japan Judo Federation 東京都文京区春日1-16-30
} 
手の健康状態に関して評価検討した.

\section{II. 対象と方法}

\section{A. 対豖者 (Table 1)}

運動負荷試験における対象者は, 強化合宿中の ソウルオリンピック候補日本人柔道選手29名で, その内訳は男性13名 (平均年龄23.7歳)，女性16名 (平均年战17.8歳)であった。

さらに，同時期に合同合宿を行っていた全日本 クラスの男女柔道選手27名を加えた，計56名を対 象として，早朝空腹時に静脈血採血と尿採取を行 った.

Table 1. Physical cha racteristics in elite judo athletes.

\begin{tabular}{lrr}
\hline & male $(13)$ & female $(16)$ \\
\hline Age & $23.7 \pm 2.1$ & $17.8 \pm 2.5$ \\
Hight $(\mathrm{cm})$ & $171.6 \pm 7.6$ & $161.1 \pm 5.8$ \\
Weight $(\mathrm{kg})$ & $78.2 \pm 11.4$ & $63.8 \pm 11.1$ \\
$\dot{\mathrm{VO}}{ }_{2}(\mathrm{ml} / \mathrm{kg} / \mathrm{min})$ & $3.58 \pm 0.18$ & $3.38 \pm 0.23$ \\
$\mathrm{HR}($ beats $/ \mathrm{min})$ & $59.3 \pm 11.6$ & $65.8 \pm 8.3$ \\
$\mathrm{SBP}(\mathrm{mmHg})$ & $126.9 \pm 13.7$ & $117.8 \pm 7.9$ \\
$\mathrm{DBP}(\mathrm{mmHg})$ & $78.6 \pm 8.7$ & $75.5 \pm 7.8$ \\
\hline
\end{tabular}

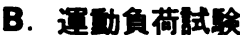

運動負荷試験として, modified Bruce protocol を用いた symptom limited treadmill exercise test を施行した．負荷試験中に心拍数や血圧を測 定するとともに, mixing chamber 法による AIC 社製 system 5 を用いて，分時換気量(以下 $\mathrm{VE}$ ), 酸素摂取量 (以下 $\dot{\mathrm{V}} \mathrm{O}_{2}$ ), 炭酸ガス排出量 (以下 $\dot{\mathrm{V}} \mathrm{CO}_{2}$ ), 呼吸商 (以下 $\mathrm{RQ}$ ), 呼気酸素濃度 (以下
$\left.\mathrm{FeO}_{2}\right)$ 等の呼気がス分析を経時的に行った。この ようにして得られた各湘定値より，functional aerobic impairment(以下 FAI), myocardial aerobic impairment (以下 MAI), heart rate impairment (以下 HRI), peripheral circulatory impairment (以下 PCI) を算出し(Table 2)，年跲や性と

Table 2. Formulas for calculation of FAI, MAI, HRI and PCI.

\begin{aligned} & \hline FAI $(\%)=\left(\right.$ Predicted $\dot{\mathrm{V}} \mathrm{O}_{2} \max -$ Observed $\left.\dot{\mathrm{V}} \mathrm{O}_{2} \max \right) \times \\ & 100 /$ Predicted $\dot{\mathrm{V}} \mathrm{O}_{2} \max \\ & \operatorname{MAI}(\%)=($ Predicted PRPmax-Observed PRPmax $) \times \\ & 100 /$ Predicted PRPmax \\ & HRI $(\%)=($ Predicted HRmax-Observed HRmax $) \times \\ & 100 /$ Predicted HRmax \\ & PCI $(\%)= \\ &$ FAI $(\%)-\operatorname{MAI}(\%)\end{aligned}$

FAI : functinal aerobic impairment MAI : myocardial aerobic impairment HRI : heartrate impairment

$\mathrm{PCI}$ : peripheral circulatory impairment

いった付加的因子を除外して，運動耐容能や最大 心機能, 最大心拍反応および末梢循環機能を評価 した ${ }^{1,3)}$.

なお，この場合の predicted $\dot{\mathrm{V}}_{2} \max$, predic. ted PRPmax および predicted HRmax とはsedentary な健常者において求められた年龄と $\dot{\mathrm{V}}_{2}$ $\max$, 年龄と PRPmax, 年龄と HRmax の回㷌式 (Table 3) に従って, 各柔道選手の年龄から予測 される $\mathrm{VO}_{2} \max , \mathrm{PRPmax}, \mathrm{HRmax}$ を意味してい る. 一方, observed $\mathrm{V}_{2} \max$, observed PRPmax, observed HRmax とは今回各柔道選手で測定され

Table 3. Calculation of predicted $\dot{\mathrm{V}} \mathrm{O}_{2} \max$, predicted HRmax and predicted PRPmax.

\begin{tabular}{c|c}
\hline Normal sedentary male & Normal sedentary female \\
\hline$\dot{\mathrm{V}} \mathrm{O}_{2} \max =55.7-0.448 \times$ Age & $\dot{\mathrm{V}} \mathrm{O}_{2} \max =42.9-0.307 \times$ Age \\
$\mathrm{r}=0.69, \mathrm{p}<0.001, \mathrm{n}=236$ & $\mathrm{r}=0.69, \mathrm{p}<0.001, \mathrm{n}=236$ \\
$\mathrm{HR} \max =218-0.92 \times$ Age & HRmax $=203-0.68 \times$ Age \\
$\mathrm{r}=0.66, \mathrm{p}<0.001, \mathrm{n}=236$ & $\mathrm{r}=0.59, \mathrm{p}<0.001, \mathrm{n}=236$ \\
$\mathrm{PRP \operatorname {max }}=438-1.59 \times$ Age & $\mathrm{PRPmax}=354-0.48 \times$ Age \\
$\mathrm{r}=0.41, \mathrm{p}<0.001, \mathrm{n}=236$ & $\mathrm{r}=0.16, \mathrm{p}<0.025, \mathrm{n}=236$ \\
\hline
\end{tabular}


た実測値を意味している.

\section{C. 㥞努性代謝闑值}

嫌気性代謝間値(以下 AT) は, Wasserman らの 方法 ${ }^{2,14}$ に従って, 呼気ガス分析より $\dot{\mathrm{VE}}$ と $\mathrm{V}^{2} \mathrm{CO}_{2}$ が急峻に上昇する部位, あるいは $\dot{\mathrm{VE}} / \dot{\mathrm{V}} \mathrm{O}_{2}$ が最 小值を示す部位を AT と規定した. そして，AT に打ける運動生理学的パラメーターを測定した.

\section{D. 血液检查と尿模査}

早朝空腹時に採血された血液にて，空腹時血糖 や腎機能, 肝機能, 脂質代謝, 横紋筇逸脱酵素等 に関して検査を行った。 また，同時に採取された 尿を用いて，一般定性検查に加えて尿沈椬を行っ た。

\section{III. 結果}

A. 最大運動負荷試験に対する反応 (Table 4, 5)

Exercise duration は男子選手で平均 $1215 \pm 86$ 秒, 女子選手で平均 $1079 \pm 71$ 秒, $\dot{\mathrm{V}} \mathrm{O}_{2} \max$ は男子 選手で $45.9 \pm 4.8 \mathrm{ml} / \mathrm{kg} / \mathrm{min}$, 女子選手で $42.1 \pm$ $4.4 \mathrm{ml} / \mathrm{kg} / \mathrm{min}$ であり，この時の $\mathrm{RQ}$ はそれぞれ
$1.048 \pm 0.047,1.034 \pm 0.049$ であった。

また，最大心拍数 (HRmax) は男子選手で平均 $183 \pm 8$ beats/min, 女子選手で平均 $182 \pm 7$ beats/ $\mathrm{min}$, 最大収縮期血圧は男子選手で $250 \pm 19 \mathrm{mmHg}$ ， 女子選手で $219 \pm 12 \mathrm{mmHg}$ であった. 最大心拍数 と最大収縮期血圧の積である PRP/100 max は男

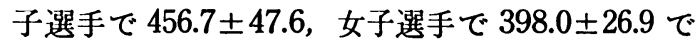
あった。

\section{B. Sedentary な健常者を基準とした運县 生理学的指標の評価 (Fig. 1,2)}

Sedentary な健常者を基準とした運動耐容能の 指標である FAI は，男子選手でー1.8 $9.9 \%$ ，女

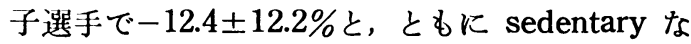
健常者の平均値 \pm 1 SD 以内の值を示した.

同様に最大心仕事量の指標である MAI は, 男

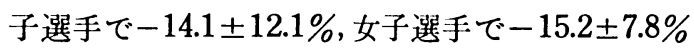
と, ともに sedentary な健常者の平均値 $-1 \mathrm{SD}$ 以下の值を示した.

Chronotropic な心機能の指標である HRI は, 男子選手で $6.9 \pm 4.2 \%$ ，女子選手で $4.7 \pm 3.7 \%$ と， ともに sedentary な健常者の平均値 $\pm 1 \mathrm{SD}$ 以内

Table 4. Maximal exercise response in male elite judo athletes ('Treadmill exercise testing with modified Bruce protocol)

\begin{tabular}{rrrrrrrrrrrrrrr}
\hline Case & Name & $\begin{array}{c}\text { Exercise } \\
\text { duration }\end{array}$ & $\mathrm{HR}$ & $\mathrm{SBP}$ & $\mathrm{PRP} / 100$ & $\dot{\mathrm{V} \mathrm{O}_{2}}$ & $\dot{\mathrm{V} C \mathrm{CO}_{2}}$ & $\mathrm{VE}$ & $\mathrm{RQ}$ & FAI & MAI & HRI & PCI \\
\hline 1 & H. S. & 1000 & 182 & 282 & 513.2 & 38.1 & 38.7 & 134.1 & 1.061 & 14.4 & -28.9 & 6.7 & 43.2 \\
2 & H. O. & 1200 & 186 & 246 & 457.6 & 46.5 & 49.3 & 157.0 & 1.061 & -0.4 & -13.1 & 6.4 & 12.7 \\
3 & T. K. & 1222 & 197 & 236 & 464.9 & 48.1 & 48.1 & 155.7 & 0.996 & -3.0 & -14.5 & 1.3 & 11.5 \\
4 & Y. Y. & 1162 & 184 & 244 & 449.0 & 41.5 & 41.9 & 127.5 & 1.008 & 4.8 & -13.6 & 4.7 & 18.4 \\
5 & Y. Y. & 1353 & 185 & 266 & 492.1 & 56.2 & 57.1 & 161.2 & 1.037 & -25.1 & -23.1 & 5.6 & -2.0 \\
6 & M. M. & 1227 & 171 & 214 & 365.9 & 47.7 & 53.2 & 154.9 & 1.114 & -6.2 & 8.5 & 12.7 & -14.7 \\
7 & Y. H. & 1118 & 193 & 260 & 501.8 & 40.7 & 42.5 & 155.6 & 1.045 & 8.6 & -26.0 & 1.0 & 34.6 \\
8 & A. O. & 1190 & 180 & 258 & 464.4 & 41.8 & 47.1 & 131.0 & 1.127 & 4.3 & -17.5 & 6.8 & 21.8 \\
9 & Y. O. & 1278 & 168 & 242 & 406.6 & 50.0 & 47.9 & 155.7 & 0.959 & -11.2 & -1.7 & 14.3 & -9.5 \\
10 & T. M. & 1288 & 185 & 262 & 484.7 & 45.3 & 46.6 & 143.5 & 1.030 & 0.3 & -20.7 & 6.0 & 21.1 \\
11 & T. H. & 1271 & 189 & 274 & 517.9 & 47.1 & 49.4 & 145.2 & 1.050 & -5.8 & -30.0 & 3.1 & 24.3 \\
12 & M. O. & 1280 & 184 & 244 & 449.0 & 51.3 & 57.4 & 121.2 & 1.120 & -10.7 & -11.0 & 7.4 & 0.2 \\
13 & T. K. & 1208 & 170 & 218 & 370.6 & 42.9 & 45.7 & 113.8 & 1.065 & 6.4 & 8.0 & 14.0 & -1.6 \\
\hline mean & & 1215 & 183 & 250 & 456.7 & 45.9 & 48.1 & 142.8 & 1.048 & -1.8 & -14.1 & 6.9 & 12.3 \\
\pm SD & & \pm 86 & \pm 8 & \pm 19 & \pm 47.6 & \pm 4.8 & \pm 5.3 & \pm 15.0 & \pm 0.047 & \pm 9.9 & \pm 12.1 & \pm 4.2 & \pm 16.5 \\
\hline
\end{tabular}

Exercise duration : sec, HR: beats $/ \mathrm{min}, \mathrm{SBP}: \mathrm{mmHg}, \mathrm{PRP}: \mathrm{mmHg} \bullet$ beats $/ \mathrm{min}, \dot{\mathrm{V}} \mathrm{O}_{2}: \mathrm{ml} / \mathrm{kg} / \mathrm{min}, \dot{\mathrm{V}} \mathrm{CO}_{2}:$ $\mathrm{ml} / \mathrm{kg} / \mathrm{min}, \mathrm{VE}: l / \mathrm{min}, \mathrm{FAI}: l / \mathrm{min}, \mathrm{FAI}: \%, \mathrm{MAI}: \%, \mathrm{HRI}: \%, \mathrm{PCI}: \%$ 
Table 5. Maximal exercise response in female elite judo athletes (Treadmill exercise testing with modified Bruce protocol)

\begin{tabular}{rrrrrrrrrrrrrr}
\hline Case & Name & $\begin{array}{c}\text { Exercise } \\
\text { duration }\end{array}$ & HR & SBP & PRP/100 & $\dot{\mathrm{VO}_{2}}$ & $\dot{\text { VCO }}{ }_{2}$ & VE & RQ & FAI & MAI & HRI & PCI \\
\hline 1 & K. Y. & 1151 & 185 & 236 & 436.6 & 49.7 & 53.9 & 444.6 & 1.084 & -38.7 & -27.3 & 1.3 & -11.4 \\
2 & F. E. & 964 & 177 & 190 & 336.3 & 37.5 & 38.5 & 68.6 & 1.028 & 1.4 & 2.9 & 7.9 & -1.5 \\
3 & N. M. & 1229 & 188 & 222 & 417.4 & 50.6 & 49.6 & 103.8 & 1.037 & -33.2 & -20.5 & 2.1 & -12.7 \\
4 & N. M. & 1023 & 188 & 204 & 383.5 & 39.2 & 40.5 & 107.7 & 1.032 & -7.5 & -11.5 & 0.4 & 4.0 \\
5 & M. A. & 1162 & 189 & 226 & 427.1 & 46.2 & 46.5 & 109.3 & 1.007 & -20.6 & -23.2 & 2.0 & 2.5 \\
6 & Y. T. & 1133 & 177 & 214 & 378.8 & 40.2 & 37.6 & 118.0 & 1.000 & -11.2 & -10.3 & 5.9 & -1.0 \\
7 & Y. A. & 1040 & 168 & 236 & 396.5 & 40.6 & 38.8 & 102.8 & 1.007 & -5.9 & -14.3 & 12.9 & 8.4 \\
8 & Y. S. & 1019 & 188 & 214 & 402.3 & 34.8 & 36.4 & 132.3 & 1.097 & 6.1 & -16.7 & 1.1 & 22.8 \\
9 & H. K. & 1049 & 178 & 222 & 395.2 & 45.8 & 39.4 & 110.6 & 0.906 & -20.6 & -14.1 & 7.3 & -6.5 \\
10 & T. M. & 987 & 185 & 228 & 421.8 & 35.8 & 40.2 & 124.6 & 1.136 & 5.8 & -21.8 & 3.7 & 27.6 \\
11 & A. O. & 1050 & 184 & 218 & 401.1 & 41.1 & 42.5 & 123.8 & 1.064 & -9.1 & -16.0 & 3.9 & 6.9 \\
12 & A. S. & 1074 & 174 & 210 & 365.4 & 43.6 & 43.0 & 113.1 & 1.003 & -18.5 & -6.1 & 8.1 & -12.4 \\
13 & R. Y. & 1120 & 184 & 222 & 408.5 & 40.7 & 42.5 & 131.6 & 1.046 & -8.8 & -18.3 & 3.5 & 9.5 \\
14 & Y. E. & 1135 & 189 & 232 & 438.5 & 44.4 & 45.2 & 93.5 & 1.018 & -16.9 & -26.6 & 1.6 & 9.7 \\
15 & M. T. & 1115 & 187 & 210 & 392.7 & 44.3 & 45.9 & 103.1 & 1.036 & -18.6 & -13.7 & 2.0 & -4.9 \\
16 & E. S. & 1012 & 171 & 214 & 368.9 & 39.5 & 37.1 & 115.2 & 1.036 & -3.8 & -5.7 & 11.0 & 1.8 \\
\hline mean & & 1079 & 182 & 219 & 398.0 & 42.1 & 42.4 & 110.8 & 1.034 & -12.4 & -15.2 & 4.7 & 2.7 \\
\pm SD & & \pm 71 & \pm 7 & \pm 12 & \pm 26.9 & \pm 4.4 & \pm 4.7 & \pm 15.0 & \pm 0.049 & \pm 12.2 & \pm 7.8 & \pm 3.7 & \pm 11.2 \\
\hline
\end{tabular}

Exercise duration : sec, $\mathrm{HR}:$ beats $/ \mathrm{min}, \mathrm{SBP}: \mathrm{mmHg}, \mathrm{PRP}: \mathrm{mmHg} \bullet$ beats $/ \mathrm{min}, \dot{\mathrm{V}} \mathrm{O}_{2}: \mathrm{ml} / \mathrm{kg} / \mathrm{min}, \dot{\mathrm{V}} \mathrm{CO}_{2}$ : $\mathrm{ml} / \mathrm{kg} / \mathrm{min}, \mathrm{VE}: l / \mathrm{min}, \mathrm{FAI}: \%, \mathrm{MAI}: \%, \mathrm{HRI}: \%, \mathrm{PCI}: \%$
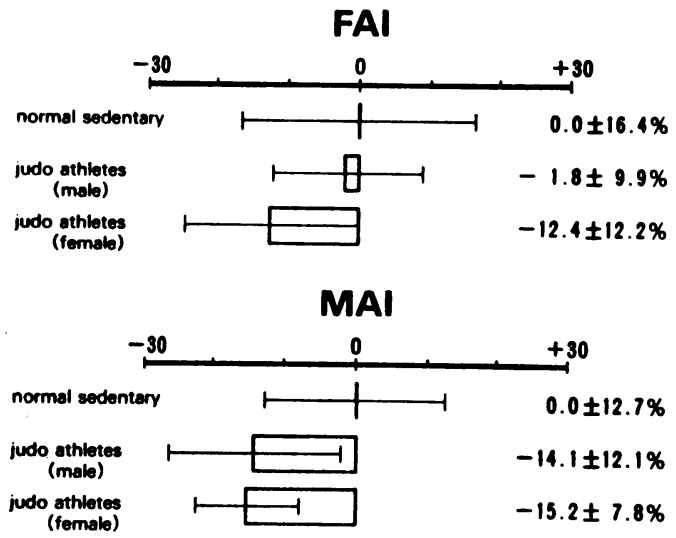

Fig. 1. Functional aerobic impairment(FAI) and myocardial aerobic impairment (MAI)in elite judo athletes. FAI is not significantly different from normal sedentary subjects, but MAI is significantly lower than normal sed. entary subjects.

の值を示した.

末梢循環機能の指標である PCI は，男子選手で $12.3 \pm 16.5 \%$ ，女子選手で $2.7 \pm 11.2 \%$ と, seden.

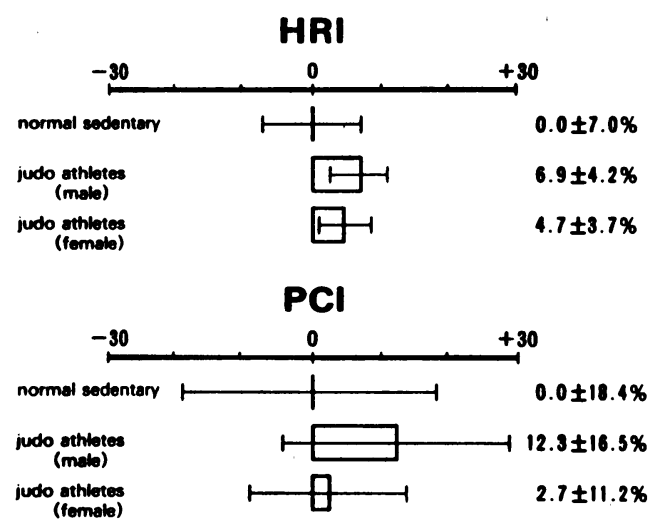

Fig. 2. Heart rate impairment(HRI)and peripheral circulatory impairment (PCI) in elite judo atheletes. HRI and PCI are not significantly different from normal sedentary subjects.

tary な健常者の平均値 \pm 1 SD 以内の値を示した.

C. 安蜨時およひ頜荷心国图所見 (Table 6)

男子選手の $61.5 \%$,女子選手の $31.2 \%$ に安静時心 電図異常が認められた. その多くは完全右脚ブロ 
Table 6. Resting and exercise ECG findings in elite judo athletes.

\begin{tabular}{lcc}
\hline resting ECG findings & $\begin{array}{c}\text { male } \\
(13)\end{array}$ & $\begin{array}{c}\text { female } \\
(16)\end{array}$ \\
\hline normal & $5(38.5 \%)$ & $11(68.8 \%)$ \\
\hline abnormal & $8(61.5 \%)$ & $5(31.2 \%)$ \\
CRBBB & $6(46.2 \%)$ & $4(25.0 \%)$ \\
sinus bradycardia & $2(15.4 \%)$ & 0 \\
PVC & 0 & $1(6.3 \%)$ \\
\hline & & \\
\hline exercise ECG findings & male & female \\
\hline normal & $11(84.6 \%)$ & $14(87.5 \%)$ \\
\hline abnormal & $2(15.4 \%)$ & $2(12.5 \%)$ \\
ischemic ST change & $1(7.7 \%)$ & $1(6.3 \%)$ \\
exercise induced PVC & $1(7.7 \%)$ & $1(6.3 \%)$ \\
\hline
\end{tabular}

ックであり，洞性徐脈は男子選手で 2 名(15.4\%)， 心室性期外収絔が女子選手で 1 名 $(6.2 \%)$ に認め られた。また，負荷心電図異常は男子選手 2 名 (15.4\%)，女子選手 2 名 $(12.5 \%)$ に認められた. その内訳は虚血性 ST 変化がそれぞれ 1 名ずつ, 心室性期外収縮がそれぞれ 1 名ずつであった。
D. ATにおける運動生理学的反応 (Table 7, 8)

男子選手の AT に怙ける $\dot{\mathrm{V}}_{2}$ は $26.4 \pm 3.4 \mathrm{~m} l /$ $\mathrm{kg} / \mathrm{min}, \mathrm{HR}$ は $132 \pm 8$ beats $/ \mathrm{min}$ で, \% $\mathrm{V}_{2} \max$ は $57.5 \pm 3.3 \% ％ \mathrm{HRmax}$ は $72.4 \pm 3.8 \% ， \mathrm{RQ}$ $0.818 \pm 0.050$ であった．同様に，女子選手の $\dot{\mathrm{V}}_{2}$ は24.0 $\pm 3.1 \mathrm{~m} / \mathrm{kg} / \mathrm{min}, \mathrm{HR}$ は $137 \pm 12$ beats $/ \mathrm{min}$ で, \% $\mathrm{VO}_{2} \max$ は $57.0 \pm 4.3 \%, \% \mathrm{HRmax}$ は $75.2 \pm$ $5.3 \%, \mathrm{RQ}$ は $0.782 \pm 0.042$ であった。

\section{E. 血液生化学検查所胃 (Table 9)}

血液生化学検査值では， $\mathrm{CPK}$ が全選手の $95 \%$ で高値 $(864 \pm 749 \mathrm{IU})$ を示し，LDH(519 $261 \mathrm{IU})$ や GOT $(51.5 \pm 104.7 \mathrm{IU})$ もとれぞれ $86 \%$ ，52\%の 選手で高值を示したななかでも非强化女子選手の 一人では, CPK が5000IU, LDH が $2180 \mathrm{IU}$, GOT が $820 \mathrm{IU}$ と著明な上昇が認められた，その 他の検查値で異常頻度の高いものとしては, 高尿 酸血症(UA 高值)が $57 \%$, 高コレステロール血症 (TC 高值)が 11\%の選手でそれぞれ認められた. なお，空腹時血桾が $140 \mathrm{mg} / \mathrm{d} l$ と異常値を呈した 男子柔道選手では, 総コレステロール值が 239 $\mathrm{mg} / \mathrm{d} l$, 中性脂肪 $(\mathrm{TG})$ 值か $849 \mathrm{mg} / \mathrm{d} l$, 尿酸值が $8.8 \mathrm{mg} / \mathrm{d} l$ と異常高值を示寸以外飞, ALP や $\gamma \mathrm{GTP}$

Table 7. Exercise response at anaerobic threshold (AT) in male elite judo athletes.

\begin{tabular}{|c|c|c|c|c|c|c|c|c|c|c|c|}
\hline Case & Name & HR & $\% \mathrm{HR} \max$ & SBP & $\mathrm{PRP} / 100$ & $\% \mathrm{PRP} / 100 \max$ & $\dot{\mathrm{V}} \mathrm{O}_{2}$ & $\% \dot{\mathrm{V}} \mathrm{O}_{2} \max$ & $\dot{\mathrm{V}} \mathrm{CO}_{2}$ & VE & $\mathrm{RQ}$ \\
\hline 1 & H. S. & 131 & 72.0 & 206 & 269.9 & 52.6 & 20.8 & 54.6 & 15.7 & 60.9 & 0.756 \\
\hline 2 & H. O. & 130 & 69.9 & 180 & 234.0 & 51.1 & 24.3 & 52.2 & 18.5 & 54.3 & 0.762 \\
\hline 3 & T. K. & 132 & 67.0 & 168 & 221.8 & 47.7 & 26.1 & 54.2 & 19.6 & 64.3 & 0.750 \\
\hline 4 & Y. Y. & 139 & 75.5 & 198 & 275.2 & 61.3 & 24.0 & 57.8 & 18.8 & 49.0 & 0.784 \\
\hline 5 & $\mathrm{Y} . \mathrm{Y}$. & 132 & 71.4 & 234 & 308.9 & 62.8 & 33.3 & 59.3 & 27.3 & 70.3 & 0.819 \\
\hline 6 & M. M. & 119 & 69.6 & 180 & 214.2 & 58.5 & 28.3 & 59.2 & 22.1 & 64.5 & 0.782 \\
\hline 7 & Y. H. & 149 & 77.2 & 208 & 309.9 & 61.8 & 23.1 & 56.9 & 20.1 & 69.3 & 0.868 \\
\hline 8 & A. 0 . & 133 & 73.9 & 210 & 279.3 & 60.1 & 23.5 & 56.2 & 19.0 & 55.4 & 0.810 \\
\hline 9 & Y. O. & 137 & 81.6 & 184 & 252.1 & 62.0 & 26.2 & 52.4 & 20.6 & 61.5 & 0.786 \\
\hline 10 & T. M. & 134 & 72.4 & 194 & 260.0 & 53.6 & 26.8 & 59.1 & 23.5 & 68.0 & 0.879 \\
\hline 11 & T. H. & 133 & 70.4 & 218 & 289.9 & 56.0 & 29.1 & 61.8 & 26.5 & 61.9 & 0.876 \\
\hline 12 & M. 0 . & 135 & 73.4 & 184 & 248.4 & 55.3 & 31.8 & 62.1 & 32.1 & 63.9 & 0.888 \\
\hline 13 & T. K. & 115 & 67.7 & 148 & 170.2 & 45.9 & 26.6 & 62.1 & 23.2 & 58.5 & 0.869 \\
\hline mean & & 132 & 72.4 & 193 & 256.4 & 56.1 & 26.4 & 57.5 & 22.1 & 61.7 & 0.818 \\
\hline$\pm \mathrm{SD}$ & & \pm 8 & \pm 3.8 & \pm 22 & \pm 38.0 & \pm 5.4 & \pm 3.4 & \pm 3.3 & \pm 4.3 & \pm 5.9 & \pm 0.050 \\
\hline
\end{tabular}

$\mathrm{HR}:$ beats $/ \mathrm{min}, \mathrm{SBP}: \mathrm{mmHg}, \mathrm{PRP}: \mathrm{mmHg} \cdot$ beats $/ \mathrm{min}, \dot{\mathrm{V}} \mathrm{O}_{2}: \mathrm{ml} / \mathrm{kg} / \mathrm{min}, \dot{\mathrm{V} C O}{ }_{2}: \mathrm{ml} / \mathrm{kg} / \mathrm{min}, \mathrm{VE}: l / \mathrm{min}$ 
Table 8. Exercise response at anaerobic threshold (AT) in female elite judo athletes.

\begin{tabular}{rrrrrrrrrrrr}
\hline Case & Name & HR & $\%$ HRmax & SBP & PRP/100 & $\%$ PRP/100 max & V $\mathrm{O}_{2}$ & $\%$ V $_{2} \max$ & $\dot{V} \mathrm{CO}_{2}$ & VE & RQ \\
\hline 1 & K. Y. & 147 & 79.5 & 220 & 323.4 & 74.1 & 29.2 & 58.7 & 25.5 & 45.6 & 0.873 \\
2 & F. E. & 148 & 83.6 & 174 & 257.5 & 76.6 & 24.4 & 65.1 & 17.1 & 41.8 & 0.702 \\
3 & N. M. & 165 & 87.8 & 174 & 287.1 & 68.8 & 31.7 & 62.7 & 24.9 & 51.8 & 0.785 \\
4 & N. M. & 140 & 74.5 & 166 & 232.4 & 60.6 & 24.4 & 62.4 & 18.7 & 44.9 & 0.764 \\
5 & M. A. & 139 & 73.5 & 186 & 258.5 & 60.5 & 26.3 & 56.9 & 20.7 & 48.0 & 0.789 \\
6 & Y. T. & 129 & 72.9 & 174 & 224.5 & 59.3 & 25.3 & 62.9 & 17.2 & 56.3 & 0.680 \\
7 & Y. A. & 126 & 75.0 & 180 & 226.8 & 57.2 & 21.8 & 53.7 & 16.9 & 46.8 & 0.774 \\
8 & Y. S. & 131 & 69.7 & 164 & 214.8 & 53.4 & 19.8 & 57.0 & 15.9 & 56.1 & 0.803 \\
9 & H. K. & 133 & 74.7 & 150 & 199.5 & 50.5 & 22.9 & 50.0 & 18.1 & 47.2 & 0.789 \\
10 & T. M. & 124 & 67.0 & 170 & 210.8 & 50.0 & 19.6 & 54.6 & 16.8 & 49.7 & 0.797 \\
11 & A. O. & 137 & 74.2 & 178 & 243.9 & 60.8 & 22.7 & 55.1 & 18.0 & 46.4 & 0.794 \\
12 & A. S. & 117 & 67.2 & 158 & 184.9 & 50.6 & 22.0 & 50.5 & 16.9 & 47.6 & 0.767 \\
13 & R. Y. & 144 & 78.3 & 182 & 262.1 & 64.2 & 23.7 & 58.3 & 19.2 & 42.9 & 0.801 \\
14 & Y. E. & 150 & 79.4 & 176 & 264.0 & 60.2 & 24.4 & 54.9 & 20.0 & 41.9 & 0.819 \\
15 & M. T. & 136 & 72.7 & 174 & 236.6 & 60.3 & 24.0 & 54.0 & 18.6 & 39.3 & 0.778 \\
16 & E. S. & 124 & 72.5 & 170 & 210.8 & 57.6 & 21.4 & 53.6 & 16.8 & 42.2 & 0.793 \\
\hline mean & & 137 & 75.2 & 175 & 239.9 & 60.3 & 24.0 & 57.0 & 18.8 & 46.8 & 0.782 \\
\pm SD & & \pm 12 & \pm 5.3 & \pm 15 & \pm 33.9 & \pm 7.5 & \pm 3.1 & \pm 4.3 & \pm 2.7 & \pm 4.7 & \pm 0.042 \\
\hline
\end{tabular}

HR : beats $/ \mathrm{min}, \mathrm{SBP}: \mathrm{mmHg}, \mathrm{PRP}: \mathrm{mmHg} \cdot$ beats $/ \mathrm{min}, \dot{\mathrm{V}} \mathrm{O}_{2}: \mathrm{ml} / \mathrm{kg} / \mathrm{min}, \dot{\mathrm{V} C O}{ }_{2}: \mathrm{ml} / \mathrm{kg} / \mathrm{min}, \mathrm{VE}: l / \mathrm{min}$

Table 9. Blood biochemical findings in judo athletes.

\begin{tabular}{|c|c|c|c|}
\hline & \multirow{2}{*}{$\begin{array}{c}\text { male } \\
\text { elite } \\
(16)\end{array}$} & \multicolumn{2}{|c|}{ female } \\
\hline & & $\begin{array}{c}\text { elite } \\
(16)\end{array}$ & $\begin{array}{l}\text { non elite } \\
\quad(24)\end{array}$ \\
\hline (normal range) & $\begin{array}{c}\text { mean } \pm \mathrm{SD} \\
\text { (abnormal number) }\end{array}$ & $\begin{array}{c}\text { mean } \pm \mathrm{SD} \\
\text { (abnormal number) }\end{array}$ & $\begin{array}{c}\text { mean } \pm \mathrm{SD} \\
\text { (abnormal number) }\end{array}$ \\
\hline $\mathrm{TP}(6.8-8.2)$ & $7.4 \pm 0.4(0)$ & $6.8 \pm 0.4(0)$ & $6.9 \pm 0.4 \quad(0)$ \\
\hline $\operatorname{Alb}(3.4-5.0)$ & $4.3 \pm 0.2(0)$ & $4.2 \pm 0.2(0)$ & $4.2 \pm 0.2 \quad(0)$ \\
\hline BUN(6-20) & $18.1 \pm 3.4(4)$ & $15.9 \pm 4.6(3)$ & $15.1 \pm 3.4 \quad(1)$ \\
\hline $\mathrm{Cr}(0.6-1.3)$ & $1.1 \pm 0.1(0)$ & $1.0 \pm 0.1(0)$ & $0.9 \pm 0.1 \quad(0)$ \\
\hline $\mathrm{UA}(2.5-5.4)$ & $7.0 \pm 1.3(5)$ & $5.8 \pm 1.1(10)$ & $6.0 \pm 1.4$ \\
\hline $\mathrm{CPK}(32-180)$ & $631 \pm 343(15)$ & $904 \pm 670(15)$ & $993 \pm 946 \quad(23)$ \\
\hline GOT $(9-33)$ & $31.8 \pm 10.0(5)$ & $42.6 \pm 20.0(8)$ & $70.6 \pm 156.7(16)$ \\
\hline GPT (4-55) & $24.2 \pm 8.8(0)$ & $25.9 \pm 8.0(0)$ & $32.9 \pm 46.2(1)$ \\
\hline $\mathrm{LDH}(200-360)$ & $375 \pm 88 \quad(9)$ & $541 \pm 135(16)$ & $600 \pm 348$ \\
\hline $\operatorname{ALP}(68-220)$ & $146 \pm 41 \quad(1)$ & $150 \pm 46 \quad(0)$ & $143 \pm 35 \quad(0)$ \\
\hline$\gamma \mathrm{GTP}(4-45)$ & $27.4 \pm 28.6(2)$ & $10.8 \pm 5.8(0)$ & $9.6 \pm 5.0 \quad(0)$ \\
\hline $\mathrm{TC}(120-230)$ & $185 \pm 38 \quad(4)$ & $167 \pm 34 \quad(1)$ & $162 \pm 35 \quad(1)$ \\
\hline TG(39-93) & $143 \pm 185(1)$ & $58 \pm 23(1)$ & $67 \pm 31 \quad(2)$ \\
\hline HDL-C (39-93) & $62.5 \pm 11.7(0)$ & $68.6 \pm 14.5(3)$ & $65.5 \pm 14.8(1)$ \\
\hline FBS $(70-105)$ & $86.3 \pm 15.9(1)$ & $83.2 \pm 7.4(0)$ & $84.4 \pm 6.2 \quad(0)$ \\
\hline
\end{tabular}


といった胆道采酵素の上昇も認められた.

\section{F. 尿模查所胃 (Table 10)}

尿検査では，全選手中 12 名 $(21.4 \%$ )に何等かの 異常所見を認めた．その内訳は，血尿や蛋白尿を 認める選手が 6 名 $(10.7 \%)$ と最も頻度が高く，尿 糖陽性の選手が 1 名(1.8\%)，尿潜血反応陽性にも かかわらず尿沈椬上赤血球を認めない選手が 1 名 (1.8\%)，ケトン尿を認める選手が 4 名 $(7.1 \%)$ で あった。

なお，尿糖を認めた男子選手は血液生化学検査 にて高血糖を呈し，尿潜血反応陽性にもかかわら ず尿沈渣上赤血球を認めなかった女子選手は，同 様に筋逸脱酵素が異常高值を呈した.

Table 10. Urinary findings in judo athletes.

\begin{tabular}{|c|c|c|c|}
\hline & \multirow{2}{*}{$\begin{array}{c}\text { male } \\
\text { elite } \\
(16)\end{array}$} & \multicolumn{2}{|c|}{ female } \\
\hline & & $\begin{array}{c}\text { elite } \\
(16)\end{array}$ & $\begin{array}{l}\text { non elite } \\
(24)\end{array}$ \\
\hline normal & $14(87.5 \%)$ & $13(81.3 \%)$ & $17(70.8 \%)$ \\
\hline abnormal & $2(12.5 \%)$ & $3(18.7 \%)$ & $7(29.2 \%)$ \\
\hline hematuria & 0 & 2 & 1 \\
\hline proteinuria & 1 & 0 & 1 \\
\hline $\begin{array}{l}\text { hematuria } \\
\quad \& \text { proteinuria }\end{array}$ & $0(6.3 \%)$ & $0(12.5 \%)$ & $1(12.5 \%)$ \\
\hline $\begin{array}{l}\text { proteinuria } \\
\quad \& \text { glycosuria }\end{array}$ & $1(6.3 \%)$ & 0 & 0 \\
\hline $\begin{array}{l}\text { suspected } \\
\text { myoglobinuria }\end{array}$ & 0 & 0 & $1(4.2 \%)$ \\
\hline ketonuria & 0 & $1(6.3 \%)$ & $3(12.5 \%)$ \\
\hline
\end{tabular}

IV. 考

案

持久力を必要とするスポーツ選手を対象とした 運動耐容能の評価，あるいは虚血性心疾患患者を 含めた各種疾患患者を対象とした運動耐容能の評 価は幅広くなされている.しかし，柔道のような いわゆる格闘技の選手を対象とした運動生理学的 研究は非常に稀である ${ }^{9,12)}$. むしてや,オリンピ ック候補選手の運動耐容能や心機能, 末梢循環機 能の総合的評価や，合宿中の血液生化学検査や尿 検査から選手の健康状態や練習方法等を検討した 報告は認められない。従って，今回著者らはこれ
らの問題点を総合的に評価することによって，今 後の練習方法等を検討する上での基礎的データを 提示した。

\section{A. 日本柔道㩧手の最大運功鱼荷红駼における} 通峌生理学的特徽

Kumagai9' らは平均 25.3才の男子柔道選手11名 を対象に, bicycle ergometer を用いた最大運動 負荷試験を施行し, untrained な健常者や triathletes との比較を行っている. その結果，柔道選 手の平均 $\dot{\mathrm{V}_{2}} \max$ は $44.1 \mathrm{ml} / \mathrm{kg} / \mathrm{min}$ で, untrained な健常者 $(42.1 \mathrm{ml} / \mathrm{kg} / \mathrm{min})$ とは有意な差 を認めないものの, triathletes $(58.9 \mathrm{ml} / \mathrm{kg} / \mathrm{min})$ に比較して有意に劣っており，柔道選手の最大心 拍数 (184 beats/min) は triathletes ( 178 beats/ min) と同様に, untrained な健常者に比較して低 值を示したと述べている. また, Tsopanakis ら ${ }^{131}$ もオリンピック柔道選手の $\dot{\mathrm{V}}_{2} \max$ が平均 47.52 $\mathrm{ml} / \mathrm{kg} / \mathrm{min}$ であり, sedentary な健常者とほぼ同 様であったと報告している.

今回の著者らの結果にても，日本を代表する一 流柔道選手といえども，その運動耐容能は女子選 手では sedentary な健常者に比較してやや勝って はいるものの，男子選手ではほぼ同程度であるこ とが認められた。これは持久力を要する中長距離 選手やクロスカントリースキーヤーに比較して劣 っているばかりではなく ${ }^{8)}$ ，柔道と同様の格闘技 であるレスリング選手やボクシング選手に比較し ても明らかに低いようである ${ }^{12,13)}$.

一方，柔道選手の最大心拍反応は sedentaryな 健常者に比較してやや劣っているものの, 1 SD 以 内の值を示した. Kumagai らの報告9) との違いは, 単に評価法の差であると考えられた。 また，最大 心拍反応に有意な差を認めないにもかかわらず， 最大心仕事量が勝っていることは，運動負荷試験 に対する血圧反応が過度であることを示唆してい るものと考えられた。また，末梢循環機能は sedentary な健常者とほぼ同程度であった。

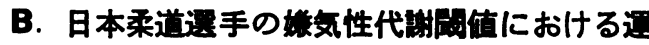 功生理学的反底}

Davis らの20才代前半の sedentary な学生を対 象に行った研究によると ${ }^{21}$, treadmill を用いての 
AT に打ける \% $\mathrm{V}_{2} \max$ は平均 $58.6 \%$ であった と報告している. また，Kindermann らの各種の 運動選手を対象とした研究では ${ }^{8)}$, 長距離ランナ 一のAT における \% $\mathrm{V}_{2} \max$ が平均 $89 \%$ である のを最高に, 中距離ランナーやクロスカントリー スキーヤー，400 $\mathrm{m}$ 走選手等でも $80 \%$ 以上であっ たとしている，以上を考慮した場合，柔道選手の 嫌気性代謝闘値における運動生理学的反応は aerobic exercise training を継続している選手とは 異なり，むしろ sedentary な健常者と同様である ものと考えられた。

\section{C. 日本柔道選手の血液模査および尿検査所見} 血液生化学検査で認められる柔道選手の異常 は，横紋笳逸脱酵素の上昇が最も著明であり，頻 度も高い，伊藤ら ${ }^{6)}$ は各種の運動形態における， これらの酵素の上昇程度に関して検討している. その結果によると，これら横紋筋逸脱酵素の上昇 はウエイトトレーニングに比してマラソンの方が 上昇程度は高く，運動直後よりは12～24時間後で より高値を示すと述べている. しかし、 マランン においてですら, CPK が約 $1400 \mathrm{IU}, \mathrm{LDH}$ が 1200 IU, GOT が 68.3 IU に上昇するに過ぎず"11), 今回 の研究対象者のらちの非オリンピック候補の女子 選手 1 名で認められた, CPKが $5000 \mathrm{IU}, \mathrm{LDH}$ が $2180 \mathrm{IU}, \mathrm{GOT}$ が $820 \mathrm{IU}$ の異常高值と, 血尿を伴 わない、尿潜血反応陽性所見は特筆に值すると考兄 られる. 今回, 尿中のミオグロビン濃度の定量等 を行っていないため断定はできないるのの，血中 筋逸脱酵素の異常高值と関連させて考えた場合, rabdomyolysis の合併が最も疑われた. Martens ら ${ }^{101}$ は、スポーツ選手に合併した compartment syndrome 患者29名を報告しているが，内 1 名が 柔道選手であり，過度の練習によってこのような 横紋筇融解を来寸可能性も念頭に置く必要があろ 5. Rabdomyolysis は横紋筋の融解によって，大 量のミオグロビンが血中，さらには尿中に排泄さ れ，急性尿細管境死をきたすことが知られてい る゙!。このような柔道選手の生死にかかわる様な 練習態度に関しては，その指導者が充分に考慮す る必要がある.

その他の特徵として，年龄に比して高尿酸血症
や高コレステロール血症の頻度が比較的高い上う である．尿酸値の上昇は aerobic exercise に比し て anaerobic exercise でより著明であり,さらに anaerobic exercise training の継続が持続的な高 尿酸血症をもたらすとされている7゙. また，高エ ネルギー食・高プリン食の長期摂取が高尿酸血症 の原因の一つであることが力士などで立証されて (る4). 柔道選手の場合，軽量級の女子選手でよ り高率に高尿酸血症が認められていることから， 食事性因子ょりはむしろ運動性因子の方がより関 与しているものと考えられた. Tsopanakis らに よる ${ }^{13)}$ ，各種スポーツ選手を対象とした脂質代謝 の研究によると，柔道選手では sedentaryな健常 者に比較して総コレステロール值には有意な差を 認めないものの, 中性脂肪や VLDL コレステロ ールは有意に低值を示し，HDL コレステロール は有意に高值を示したと述べている．今回の著者 らの結果でも，HDL コレステロールは全体的に 高値を示したが，特に男子選手では中性脂肪は低 下しておらず，総コレステロール值に関してはむ しろ25\%で異常高值が認められた。このよらな差 異は, 今回の研究が強化合宿中になされたといら 影響も無視できないであろらが，特に重量級の男 子選手に多く認められることを考慮すれば，食事 による過量摂取の可能性も否定できないであろ う.

また今回の対象者の中に，糖尿病性留症が疑わ れる選手む含まれている事は，日常から選手に対 しての十分な medical check の必要性を示唆し ているものと考えられた.

\section{V. 結 語}

（1）ソウルオリンピック候補の男女柔道選手を 対象として treadmill 運動負荷試験を施行し, そ の運動生理学的特徵を評価するとともに, 血液検 査および尿検查による medical check をおこな った.

（2）女子柔道選手の運動耐容能は sedentary な 健常者に比較してやや勝っているるのの, 男子采 道選手の運動耐容能はほぼ同程度であった。

（3）最大心仕事量は男女柔道選手ともに sed- 
entary な健常者に比較して勝っているるのの, 末 梢循環機能はほぼ同程度であった。

（4）嫌気性代謝間值における\% \% \%HRmax は, sedentary な健常者とほぼ同程度 であった。

（5）血液生化学検査拉よび尿検查では横紋筋逸 脱酵素の著明な上昇以外に, 高尿酸血症や高コレ ステロール血症を示す選手の頻度が比較的高く， 糖尿病性腎症や rabdomyolysis を疑う選手も認 められた。

なお，本論文の要旨は第44回日本体力医学会大 会(1989年 9 月，札幌)に扣いて発表した.

(受付 平成 2 年 1 月 13 日)

\section{引用文 献}

1) Bruce, R. A., Kusumi, F. and Hosmer, D. (1973) : Maximal oxygen intake and normographic assessment of functional aerobic impairment in cardiovascular disease. Am Heart J. 85, 546-562.

2) Davis, J. A., Vodak, P., Wilmore, J. H., Vodak, J. and Kurtz, P. (1976): Anaerobic threshold and maximal aerobic power for modes of exercise. $\mathrm{J}$. Appl Physiol. 41, 544-550.

3) 長谷弘記, 渡部純郎, 中村良一, 矢吹 壮, 町井 潔, 李美根雄, 海老根東雄, 赤池 真, 露木和夫, 張 光哲(1985)：慢性血液透析患者の運動耐容能, 心機能怙よび末梢循環機能におよぼす運動療法の効 果. 日腎誌, 27, 1429-1436.

4) 林 盈六 (1971): 痛風発生の生活環境的考察. リウ マチ, 11, 11-17.

5）五十嵐良典, 安部良治, 鈴木真事, 関 清, 長谷 弘記, 出川敏行, 二宮健次, 海老根東雄, 矢吹 壮 (1984)：急性下肢動脈血栓症の血栓除去術施行後に myonephropatic-metabolic syndrome を合併 し, 血液透析療法にて救命し得た 1 症例. 日内誌, 73,
494-500.

6) 伊藤 朗 (1987) : 困説・運動生化学入門一生理・生 化学から運動処方まで一. 医霜薬出版, 東京, pp 131146.

7) 伊藤 朗(1987)：図説・運動生化学入門一生理・生 化学から運動処方まで一. 医歯薬出版, 東京, pp 7186.

8) Kindermann, W., Simon, G. and Keul, J. (1979) : The significance of the work load intensities during endurance training. Eur J. Appl. Physiol. 42, 25-34.

9) Kumagai, S., Nishizumi, M. and Kondo, Y.(1988): Reevaluation of contribution of physical fit ness, body weight, and different sports activity to resting blood pressure in young men. Int J. Sports Med. 9, 334-337.

10) Martens, M. A., Backaert, M., Vermaut, G. and Mulier, J. C. (1984): Chronic leg pain in athletes due to a recurrent compartment syndrome. Am J. Sports Med. 12, 148-151.

11) Ohman, E. M., Teo, K. K., Johnson, A. H., Collins, P. B., Dowsett, D. G., Ennis, J. T. and Horgan, J. H. (1982): Abnormal cardiac enzyme responses after strenous exercise : alternative diagnostic aids. Br Med. J. 285, 1523-1526.

12) Sady, S. P., Thomson, W. H., Berg, K. and Savage, M. (1984) : Physiological characteristics of highability prepubescent wrestlers. Med. Sci Sports Exerc 16, 72-76.

13) Tsopanakis, C., Kotsarellis, D. and Tsopanakis, A. D. (1986) : Lipoprotein and lipid profiles of elite athletes in olympic sports. Int. J. Sports Med. 7, 316-321.

14) Wasserman, K., Whipp, B. J., Koyal, S. N. and Beaver, W. L. (1973) : Anaerobic threshold and respiratory gas exchange during exercise. J. Appl Physiol. 35, 236-243. 